\title{
Friend or foe: the association of Labyrinthulomycetes with the Caribbean sea fan Gorgonia ventalina
}

\author{
Colleen A. Burge ${ }^{1, *}$, Nancy Douglas ${ }^{1}$, Inga Conti-Jerpe ${ }^{1,4}$, Ernesto Weil $^{2}$, \\ Steven Roberts ${ }^{3}$, Carolyn S. Friedman ${ }^{3}$, C. Drew Harvell ${ }^{1}$ \\ ${ }^{1}$ Department of Ecology and Evolutionary Biology, Cornell University, Ithaca, New York 14853, USA \\ ${ }^{2}$ Department of Marine Sciences, University of Puerto Rico, Mayaguez, Puerto Rico 00680 \\ ${ }^{3}$ School of Aquatic and Fishery Sciences, University of Washington, Seattle, Washington 98195, USA
}

${ }^{4}$ Present address: Biology and Marine Biology, University of North Carolina, Wilmington, North Carolina 28403, USA

\begin{abstract}
A new syndrome in sea fans Gorgonia ventalina consisting of multifocal purple spots (MFPS) has been observed in the Caribbean Sea. Surveys of MFPS on sea fans were conducted from 2006 to 2010 at a shallow and deep site in La Parguera, Puerto Rico (PR). At the shallow site, MFPS increased between 2006 and 2010 (site average ranged from 8 to $23 \%$ ), with differences found at depths over time using an analysis of covariance (ANCOVA, $p<0.0001$ ). As a potential causative agent we examined a Labyrinthulomycota-like ovoid parasite that was observed to be abundant in MFPS lesions in light micrographs. Labyrinhylomycetes were successfully isolated, cultured and characterized in sea fans from Florida and PR. Sequence information obtained from the small subunit (SSU) rRNA gene indicated that Labyrinthulomycetes in most sea fans (healthy and MFPS sea fans from Florida; MFPS from PR) and the cultured microorganism are in the genus Aplanochytrium, although some healthy sea fans from PR contained members of the genus Thraustochytrium. Both genera fall within the family Thraustochytriidae. Histology confirmed observations of thraustochytrids within apparently healthy and MFPS sea fans from PR, and specific staining indicated a host melanization response only in colonies containing Labyrinthulomycetes or fungal infections. Growth trials indicate that the temperature-growth optima for the cultured microorganism is $\sim 30^{\circ} \mathrm{C}$. In inoculation experiments, the cultured Aplanochytrium did not induce purple spots, and histology revealed that many of the apparently healthy recipients contained Labyrinthulomycetes prior to inoculation. Taken together, these results indicate that the Labyrinthulomycetes associated with sea fans is likely an opportunistic pathogen. Further studies are needed to understand the pathogenesis of this microorganism in sea fans and its relationship with MFPS.
\end{abstract}

KEY WORDS: Labyrinthulomycota $\cdot$ Caribbean sea fan · Gorgonia ventalina $\cdot$ Multi-focal purple spots $\cdot$ MFPS

\section{INTRODUCTION}

Visual responses of soft and hard corals to various insults such as disease, predation and competition can appear similar in a particular host. Thus, coral diseases or syndromes are often described in terms of changes of color or outward morphological features of the host. Little is known about the pathogenesis of many of these syndromes. The etiology of only 5 coral diseases has been demonstrated using Koch's postulates (reviewed by Sutherland et al. 2004, Weil et al. 2006, Harvell et al. 2007, Bourne et al. 2009). In the Caribbean sea fan coral Gorgonia ventalina, the appearance of purpled tissue is caused by an 
increase in the number of purple sclerites and is a generalized response to invading pathogens or other biotic agents (Petes et al. 2003, Alker et al. 2004, Smith \& Weil 2004, C. S. Couch et al. unpubl.). Necrotic lesions, surrounded by purple halos in G. ventalina, have been described as aspergillosis (Smith et al. 1996, Nagelkerken et al. 1997, Kim \& Harvell 2001). The terrestrial fungus Aspergillus sydowii was isolated from fans with these signs and Koch's postulates fulfilled in controlled laboratory experiments (Smith et al. 1996, Geiser et al. 1998). More recently, culture-dependent sampling showed that fungal species other than A. sydowii can be associated with lesions (ToledoHernández et al. 2008). During field surveys in Mexico, Florida, and Puerto Rico, a new type of lesion was identified (Weil \& Hooten 2009, Weil \& Rogers 2011; our Fig. 1) that is characterized by small (1 to $3 \mathrm{~mm}$ in diameter), circular to oblong multi-focal purple spots (MFPS; description after Work \& Aeby 2006).

Preliminary histological evaluation of these multi-focal purple lesions revealed the presence of a stramenophile (ovoid parasites distributed within a mucus net; Petes et al. 2003) similar in appearance to the quahog parasite unknown (QPX) parasite of clams (Ragone Calvo et al. 1998, Ragan et al. 2000) and Labyrinthula zosterae that infects marine grasses (Durako \& Kuss 1994, Ralph \& Short 2002). Labyrinthulomycetes (Labyrinthulomycota) produce a very distinctive, basophilic-staining ectoplasmic network matrix with continuity from the network matrix to the cell cytoplasm (Porter 1990). Although Labyrinthulo-
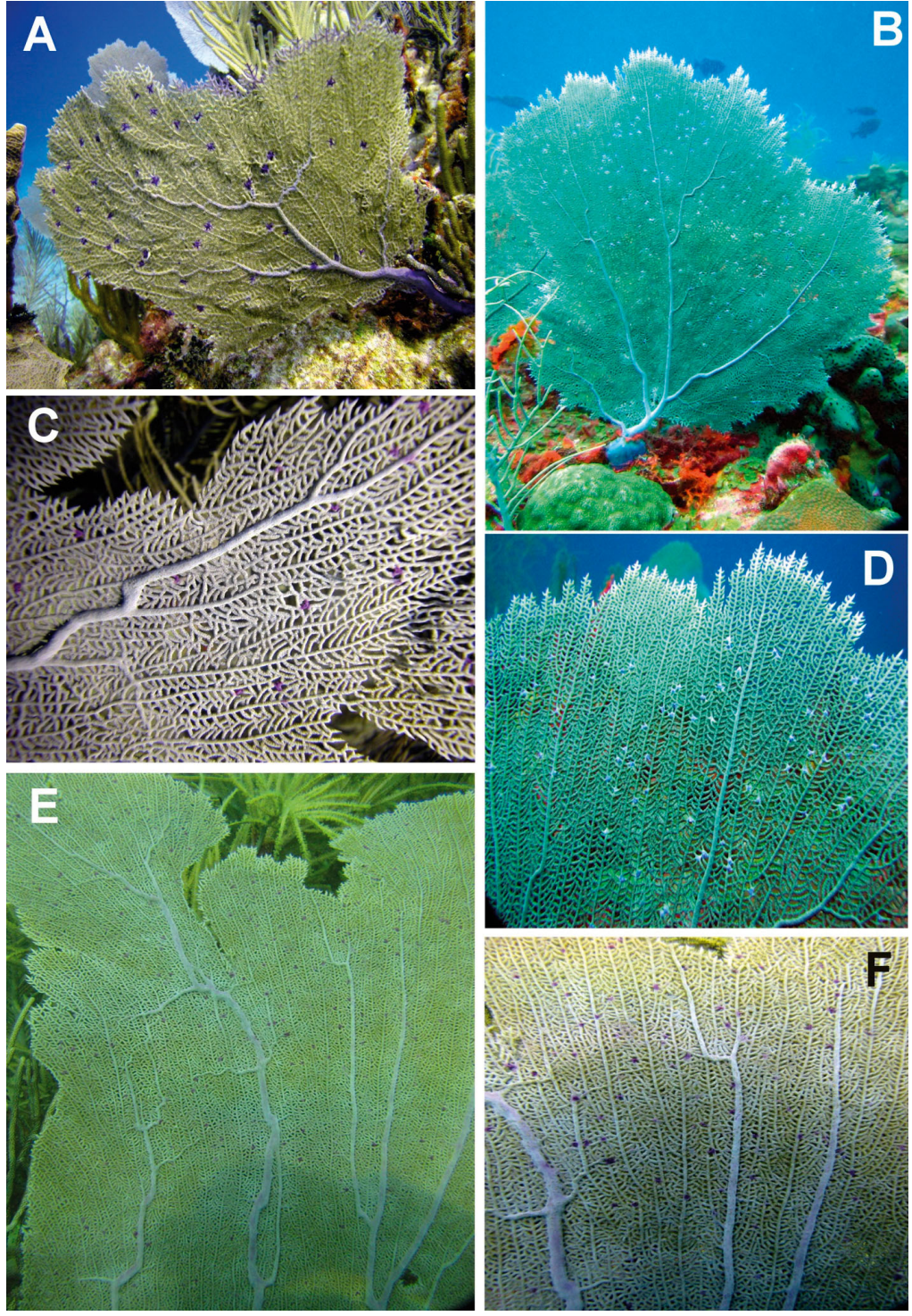

Fig. 1. Gorgonia ventalina. Colonies of sea fans with multifocal purple spot (MFPS) in different localities in the Caribbean Sea. (A) Heavily spotted small size colony at $10 \mathrm{~m}$ depth on Las Redes reef, Mexico, and (B) medium size colony at $20 \mathrm{~m}$ depth on Weimberg reef, $8 \mathrm{~km}$ off the southwest coast of Puerto Rico. (C) Close-up of regularly distributed purple spots on a branch of a sea fan and (D) several aggregated spots in a medium size colony in Grenada.

(E) Heavily spotted colony. (F) Close-up of a large G. ventalina in Curacao mycetes are common in estuarine and

marine habitats, only a few of the identified Labyrinthulomycetes appear pathogenic and have been reported to be the primary infectious agent implicated in damaging epizootics, especially in the sea grasses Zostera marina and Thalassia testudinum (Muehlstein et al. 1991, Durako \& Kuss 1994, Ralph \& Short 2002), octopus (Polglase 1980), nudibranch (McLean \& Porter 1982), abalone (Bower 1987), and the quahog clam Mercenaria mercenaria (Ragone Calvo et al. 1998, Ragan et al. 2000, Lyons et al. 2007).
Given the impact of Labyrinthulomycetes on the health of other marine invertebrates, our goal was to explore the disease dynamics of MFPS in sea fans and to characterize the Labyrinthulomycetes-like microorganism isolated from purple sea fan lesions. We surveyed sea fan disease at 2 reefs in La Parguera, Puerto Rico (PR) and collected apparently healthy and MFPS-affected Gorgonia ventalina from sites in Florida and Puerto Rico to (1) isolate the potential pathogen, (2) identify and characterize the 
Labyrinthulomycetes using histological, molecular, and culture techniques, and (3) perform preliminary inoculation experiments to fulfill Koch's postulates.

\section{MATERIALS AND METHODS}

\section{Sea fan surveys}

Puerto Rico

Sixteen $20 \mathrm{~m}^{2}$ band transects were randomly laid (4 transects per depth) at 2 reefs in La Parguera, PR - Media Luna $\left(17^{\circ} 56.093^{\prime} \mathrm{N}, 67^{\circ} 02.931^{\prime} \mathrm{W}\right)$ (at depths of 3 to $18 \mathrm{~m}$ ) and Buoy $\left(17^{\circ} 53.38^{\prime} \mathrm{N}\right.$ and $66^{\circ} 59.09^{\prime} \mathrm{W}$ ) (at depths of 18 to $25 \mathrm{~m}$ ). Transects were laid annually in September or October from 2006 to 2010 at Media Luna and 2007 to 2010 at Buoy. Along each transect all apparently healthy Gorgonia ventalina colonies and colonies with lesions were enumerated. Any purple or abnormally colored areas on the sea fans were checked carefully. Lesions were also recorded and described as follows: large irregular purple spots (aspergillosis-like; full description Work \& Aeby 2006), MFPS, predation, bleaching, and other abnormalities. Other abnormalities included growth anomalies, cyanobacteria, red band disease, etc. Signs of predation by snails (flamingo tongue) and by fireworms were noted. Prevalence (the total number of each abnormality divided by the total number of individuals) of each type of abnormality was calculated per transect, depth, and year.

MFPS prevalence data was arcsine transformed before data analysis to meet the assumptions of normality and equal variances (Zar 1999). An analysis of covariance (ANCOVA) was performed to compare depth over time (using time as the covariate) using IBM SPSS Statistics 17.0 (Insightful). Statistical differences among depths were identified using Fisher's least significant difference (LSD) test; however, due to the differences in depth and number of individuals within each site, the sites could not be compared.

\section{Sea fan collection}

Florida

From 20 sea fan colonies $(\mathrm{n}=8$ healthy and $\mathrm{n}=12$ MFPS), pieces of apparently healthy $(\mathrm{n}=8)$ and MFPS tissue $(\mathrm{n}=12), \sim 6 \times 9 \mathrm{~cm}$, were collected from Big Pine Ledges $\left(24^{\circ} 33.207^{\prime} \mathrm{N}, 81^{\circ} 22.731^{\prime} \mathrm{W}\right)$, Florida Keys in February 2010. Samples were wrapped individually in wet paper towels, placed in separate bags and shipped overnight to the University of Washington with heat packs to keep the colonies warm. Upon arrival, fans were split among 4 aquaria that each contained $32 \mathrm{ppt}$ seawater maintained at $25^{\circ} \mathrm{C}_{i} 2$ aquaria held apparently healthy sea fans and 2 contained MFPS fans. Five of the MFPS sea fans were used for parasite isolation; pieces of 6 healthy and 6 MFPS sea fans were stored in $70 \%$ ethanol for DNA analysis (see 'Molecular methods').

\section{Puerto Rico}

Apparently healthy and MFPS sea fans ( $\mathrm{n}=15$ each) were collected from Media Luna Reef, La Parguera, PR, in July 2010. Fragments from each fan were divided in half $(\sim 5 \times 5 \mathrm{~cm})$ and were flash frozen or fixed in $10 \%$ seawater buffered formalin for $24 \mathrm{~h}$ followed by storage in $70 \%$ ethanol.

\section{Labyrinthulomycetes isolation and maintenance}

Based on past descriptions of Labyrinthulomycotalike cells in sea fans located within the inner axis (Petes et al. 2003, C. S. Couch \& L. Mydlarz pers. comm.), the inner axis of sea fans from Puerto Rico and Florida were targeted for isolation. A square piece of Gorgonia ventalina tissue including the lesion and $0.5 \mathrm{~cm}$ of surrounding tissue was excised and dipped twice into $70 \%$ ethanol and filtered sea water (FSW) containing $200 \mathrm{U} \mathrm{ml}^{-1}$ penicillin, $0.2 \mathrm{mg} \mathrm{ml}^{-1}$ streptomycin, and $1 \mu \mathrm{g} \mathrm{ml}^{-1}$ fungizone (FSW+PSF). The tissue section was then placed into a fresh container of FSW+PSF, and $0.25 \mathrm{~cm}$ of tissue around the border was cut off. The remaining tissue (the lesion plus $0.25 \mathrm{~cm}$ of surrounding tissue) was used for pathogen isolation where the piece of sea fan was cut down the central axis and then chopped into smaller pieces. These pieces were placed into 4 different $25 \mathrm{~cm}^{2}$ T-flasks (Falcon) containing FSW+PSF and held for $30 \mathrm{~min}$ at room temperature. The seawater was then replaced with either QPX broth (Kleinschuster et al. 1998) containing $100 \mathrm{U} \mathrm{ml}^{-1}$ penicillin and $0.1 \mathrm{mg} \mathrm{ml}^{-1}$ streptomycin (PS) or Nutrient Broth (Difco) containing PS $\left(200 \mathrm{U} \mathrm{ml}^{-1}\right.$ penicillin, $0.2 \mathrm{mg} \mathrm{ml}^{-1}$ streptomycin). Half of the culture flasks were placed at $25^{\circ} \mathrm{C}$ and half at $30^{\circ} \mathrm{C}$ (one of each media type per temperature). Cultures were examined daily at $100 \times$ and $200 \times$ magnification for possible growth of Labyrinthulomycetes using a Nikon 
Eclipse TS100 inverted microscope equipped with an Olympus digital camera for taking photomicrographs. When a possible Labyrinthulomycota was identified, fresh QPX broth and PS were added to the flask; after approximately $5 \mathrm{~d}$, cells were scraped from the original culture and sub-cultured into a new flask with QPX broth and PS. Henceforth, every 5 to $7 \mathrm{~d}$, the cultures were sub-cultured, whereby $50 \mu \mathrm{l}$ of cells were scraped from the bottom of the flask and placed into a new flask with QPX broth and PS. No other microorganisms were present based on observations at 200x; nor have any been observed in $2 \mathrm{yr}$ of culture.

\section{Characterization of a Labyrinthulomycetes}

In culture

Photomicrographs were taken of the isolated Labyrinthulomycota using an Olympus digital camera. To obtain size estimates of the Labyrinthulomycota-like cells, $50 \mu \mathrm{l}$ aliquots of culture media containing the cells were added to a microscope slide placed in a petri dish and allowed to grow for $3 \mathrm{~d}$ at $25^{\circ} \mathrm{C}$ before staining with the Hema 3 kit (Protocol, Fisher Scientific). Photomicrographs were taken at 20x magnification, and Labyrinthulomycetes total cell length was measured using Image J 1.44 p software (NIH).

\section{Histology}

Sea fan sections, approximately $2 \times 2 \mathrm{~cm}$, were decalcified using sodium citrate buffered (5\%) formic acid $(15 \%)$, embedded in paraffin, and sectioned at the Cornell University's Veterinary Histology Laboratory (Luna 1968). De-paraffinized $5 \mu \mathrm{m}$ tissue sections from the 15 apparently healthy and 15 MFPS sea fans were stained with hematoxylin and eosin and viewed under a bright field Olympus BH-2 microscope with the Olympus DP-20 camera system. From 16 of these sea fans (8 MFPS, 8 healthy), a second tissue section was taken and stained for presence of melanin using Fontana-Mason (FM) silver stain protocol (Mydlarz et al. 2008). Stained tissue sections were examined for presence/absence of Labyrinthulomycetes cells (and cell types) or other parasites within the tissues or axial cortex, and any other tissue or cellular abnormalities including melanization. In sea fans where $>10$ Labyrinthulomycetes cells were identified, photomicrographs were taken at 20x magnification, and total cell length was measured using Image J 1.44 p software.

Molecular methods

Total genomic DNA was extracted from approximately $1 \mathrm{~cm}^{2}$ of ethanol preserved or frozen sea fan tissue using a blood and tissue DNA extraction kit (Qiagen) following the manufacturer's instructions. To better facilitate extraction, the ethanol-preserved tissue and skeleton were diced into fine pieces with a fresh razor blade prior to extractions, and the frozen tissue was ground into a fine powder in liquid nitrogen with a mortar and pestle.

Total DNA, 50 to $100 \mathrm{ng}$, (2 to $4 \mu \mathrm{l}$ ) from 5 apparently healthy and 6 MFPS sea fan tissues from Florida, 15 healthy and 15 MFPS tissues from Puerto Rico or $1 \mu \mathrm{l}$ of genomic DNA from the 2 independent cultures of the microorganism isolated as described in 'Labyrinthulomycetes isolation and maintenance' above was used as template for $25 \mu \mathrm{l}$ PCR reactions containing $1 \mathrm{U}$ of Taq DNA Polymerase (Invitrogen), $1 \times$ PCR buffer, $2 \mathrm{mM} \mathrm{MgCl} 2,0.4 \mathrm{mM}$ BSA, $0.2 \mathrm{mM}$ dNTPs, and $25 \mu \mathrm{M}$ of each primer. Labyrinthulomycota small-subunit ribosomal DNA (SSU rRNA) specific primers, Laby-A and Laby-Y, were used (Stokes et al. 2002). Cycling conditions were: $94^{\circ} \mathrm{C}$ for $30 \mathrm{~s}$, $50^{\circ} \mathrm{C}$ for $30 \mathrm{~s}, 72^{\circ} \mathrm{C}$ for $1.5 \mathrm{~min}$ for 35 cycles followed by a final $5 \mathrm{~min}$ extension at $72^{\circ} \mathrm{C}$. Five $\mu \mathrm{l}$ of each $\mathrm{PCR}$ reaction were separated on a $2 \%$ agarose/TAE gel for use in purifying the PCR products amplified from the 41 samples and 2 isolates. Those containing bands of the expected ( 430 bp size) were purified using the QIAquick PCR kit (Qiagen) and sent to the Cornell University Life Sciences Core Laboratories for direct sequencing on an Applied Biosystems Automated 3730 DNA Analyzer. Although direct sequencing of all of the PCR products showed unambiguous DNA chromatographs throughout, the homogeneity of samples was additionally confirmed by cloning the PCR products into the TOPO-TA vector, using the TOPO-TA cloning kit (Invitrogen) for sequencing of 2 to 5 clones of each isolate. The basic local alignment search tool (BLAST) algorithm (Altschul et al.1990) was used to compare resulting sequences, including the overlapping 398 nucleotides (nt) from Florida samples and 292 nt from Puerto Rico samples, with those deposited in the National Center for Biotechnology Information (NCBI) GenBank database, and alignments were made using the EMBL-EBI Clustal W tool (Larkin et al. 2007, Goujon et al. 2010). Representative se- 
quences from the cultured microorganism and sea fan isolates were submitted to GenBank (accession numbers JQ248602 and JQ248603 to JQ248606, respectively).

\section{Temperature and growth optima}

Two types of assays were used in 2 trials to quantify Labyrinthulomycota cultures: cell counts using a hemocytometer and total protein concentration. In the first trial, a Labyrinthulomycota culture held at $22^{\circ} \mathrm{C}$ was divided into 18 sub-cultures that were incubated at $15,20,25,30$, and $32^{\circ} \mathrm{C}$ in triplicate for $3 \mathrm{~d}$. Culture temperatures and incubation period were based on previous visual observations of Labyrinthulomycota growth, where over-growth of culture flasks occured after $3 \mathrm{~d}$ at temperatures of $25^{\circ} \mathrm{C}$ and higher. In the second trial, 9 sub-cultures were incubated at 20,25 , and $30^{\circ} \mathrm{C}$ in triplicate for $3 \mathrm{~d}$.

In the second trial, total protein was also assessed. After $3 \mathrm{~d}$, the media was poured off, rinsed once with $3 \mathrm{ml}$ of $0.22 \mu \mathrm{m}$-filtered artificial sea water, and replaced with $3 \mathrm{ml}$ of $0.22 \mu \mathrm{m}$-filtered artificial sea water. With a sterile wooden dowel, the bottom of each culture was scraped until no Labyrinthulomycota growth was visible on the bottom of the culture. Seven hundred $\mu \mathrm{l}$ of each culture was placed in a bead beater and mixed at $300 \mathrm{rpm}$ for $30 \mathrm{~s} ; 400 \mu \mathrm{l}$ was set aside for protein assays and $300 \mu \mathrm{l}$ for cell counts and held on ice until use.

Prior to counting using a hemocytometer, cells were vortexed for about $20 \mathrm{~s}$. In each culture, cells were counted in triplicate. In the first trial, only total cell counts were noted. In the second trial, cell types were distinguished as either trophic cells (solitary Labyrinthulomycetes cells) or sori (Labyrinthulomycetes cells containing spores) (Fig. 2). No other cell types (i.e. zoospores) were distinguishable or present.

Total protein was extracted from each sample by adding $400 \mu \mathrm{l}$ of extraction buffer, $0.15 \mu \mathrm{g} \mathrm{ml} \mathrm{m}^{-1}$ dithiothreitol (DTT) in Tris-HCl, to each tube. The contents of the tube were mixed and lysed for 2 min with the Fisherbrand disposable pestle grinder system and incubated for $45 \mathrm{~min}$ on ice for extractions. Protein was measured using the DC protein kit (BioRad) and read in triplicate using the Synergy HT multi-Detection microplate reader with KC4 software (Biotek Instruments) at $750 \mathrm{~nm}$.

Both cell counts and protein concentrations exhibited departures from normality due to high levels of variation and were log-transformed. Differences among temperature treatments and between trials

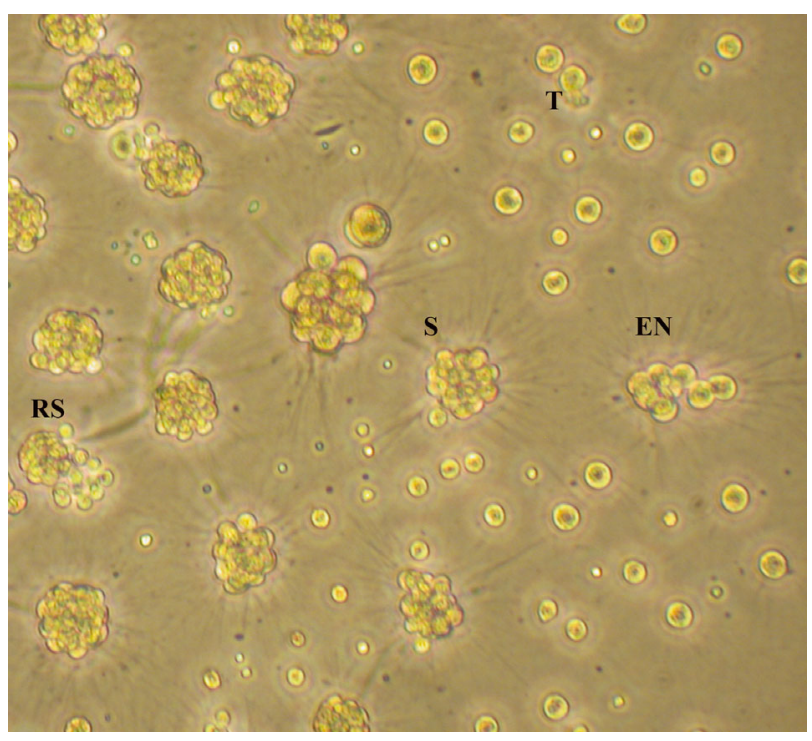

Fig. 2. Labyrinthulomycetes isolated from Gorgonia ventalina showing example cell types. All cells are connected with the ectoplasmic network (EN). T: trophic cells; S: sorus containing spores; RS: ruptured sorus

(total cell counts only) were assessed using an analysis of variance (ANOVA) and identified with the Tukey post hoc test (Zar 1999). Statistical analyses were run using IBM SPSS Statistics 17.0 (Insightful).

\section{Inoculation experiments}

Pieces $(6 \times 9 \mathrm{~cm})$ of 12 healthy Gorgonia ventalina individuals $(\mathrm{n}=2$ pieces per sea fan in Trial 1 and $\mathrm{n}=3$ pieces per sea fan in Trial 2) were collected at Laurel patch reef, La Parguera, PR (17 $56.608^{\prime} \mathrm{N}$, $67^{\circ} 03.208^{\prime}$ W) in May and September 2010, and held in situ to heal on the reef for $3 \mathrm{~d}$. Sea fans were then collected from the reef and moved into static 10 gallon (ca. 38 l) aquaria at the University of Puerto Rico, Isla Magueyes Laboratory in La Parguera. Fans were distributed equally, in a clonally replicated design, using the fragment described in 'Sea fan collection' above, and were acclimated for $2 \mathrm{~d}$. Seawater was changed daily.

In the first trial, one fragment of each of the 12 sea fans was injected with the Labyrinthulomycota culture ( 4000 cells per injection point) and the other fragment injected with the QPX media only. Specifically, the inoculum was injected into the central axis in 3 locations on the surface of each sea fan fragment, $\sim 3 \mathrm{~cm}$ apart. The sea fans were then held for a week before collection for routine paraffin histology (as described in 'Histology') where areas adjacent to the 
infection points $(\mathrm{n}=3)$ were chosen. In the second trial, similar methods were followed, except for an inclusion of a bath treatment for exposure, in addition to the injection method used in the first trial; also, the trial was extended to $14 \mathrm{~d}$. In each aquarium in the bath treatment, sea fans were exposed to $5 \mathrm{ml}$ ( 400000 cells) of Labyrinthulomycota culture for $24 \mathrm{~h}$. Temperature was held at ambient $29.2^{\circ} \mathrm{C}$ (range: 28.6 to $32.5^{\circ} \mathrm{C}$ ) in Trial 1 , and $28.8^{\circ} \mathrm{C}(28.2$ to $31.5^{\circ} \mathrm{C}$ ) in Trial 2.

\section{RESULTS}

\section{Sea fan surveys}

Puerto Rico

An average of approximately 245 (range: 243 to 247) sea fan colonies were surveyed at Media Luna (survey years: 2006 to 2010) and 150 (138 to 161) at Buoy (survey years 2005 to 2010). Survey data (nontransformed) for all abnormalities are shown in Fig. 3A,B, and trends in MFPS are shown in Fig. 3C,D. At Media Luna, MFPS exhibited positive correlations $\left(\mathrm{R}^{2}=0.674\right)$ in time $(\mathrm{p}<0.0001)$ from 2006 to 2010, with significant differences among depths $(\mathrm{p}<$
0.0001), where pairwise comparisons indicate the regression line for each depth to be different $(\mathrm{p}<$ 0.05) (total ANCOVA: $F=38.801$, df $=4, \mathrm{p}<0.0001$ ). No correlation between MFPS and time was observed at BUOY ( $p>0.05)$, and significant differences were only seen at depth where MFPS detected at $18 \mathrm{~m}$ was greater than that at 17,20 , or $25 \mathrm{~m}(\mathrm{p}<$ 0.0001; total ANCOVA: $F=10.04$, df = 4, p < 0.0001). No correlation was observed between large irregular lesions over time at Media Luna ( $p>0.05)$, although depth was significant ( $p=0.02$ ) where fans in $6 \mathrm{~m}$ of water differed from those at 3,10, and $18 \mathrm{~m}$ (total ANCOVA, $F=2418.044, \mathrm{df}=4, \mathrm{p}=0.04)$. No other variables exhibited statistically significant correlations over time or depth ( $p>0.05)$. MFPS were not correlated with any other abnormalities.

\section{Characterization of a new Labyrinthulomycetes}

In culture

After incubating tissue and skeleton of sea fans collected from Florida in QPX medium for $3 \mathrm{~d}$, Labyrinthulomycetes trophic cells were first observed in culture. After $5 \mathrm{~d}$ of growth, trophic cells, sori, and spores (Porter 1990) were observed (Fig. 2). Based
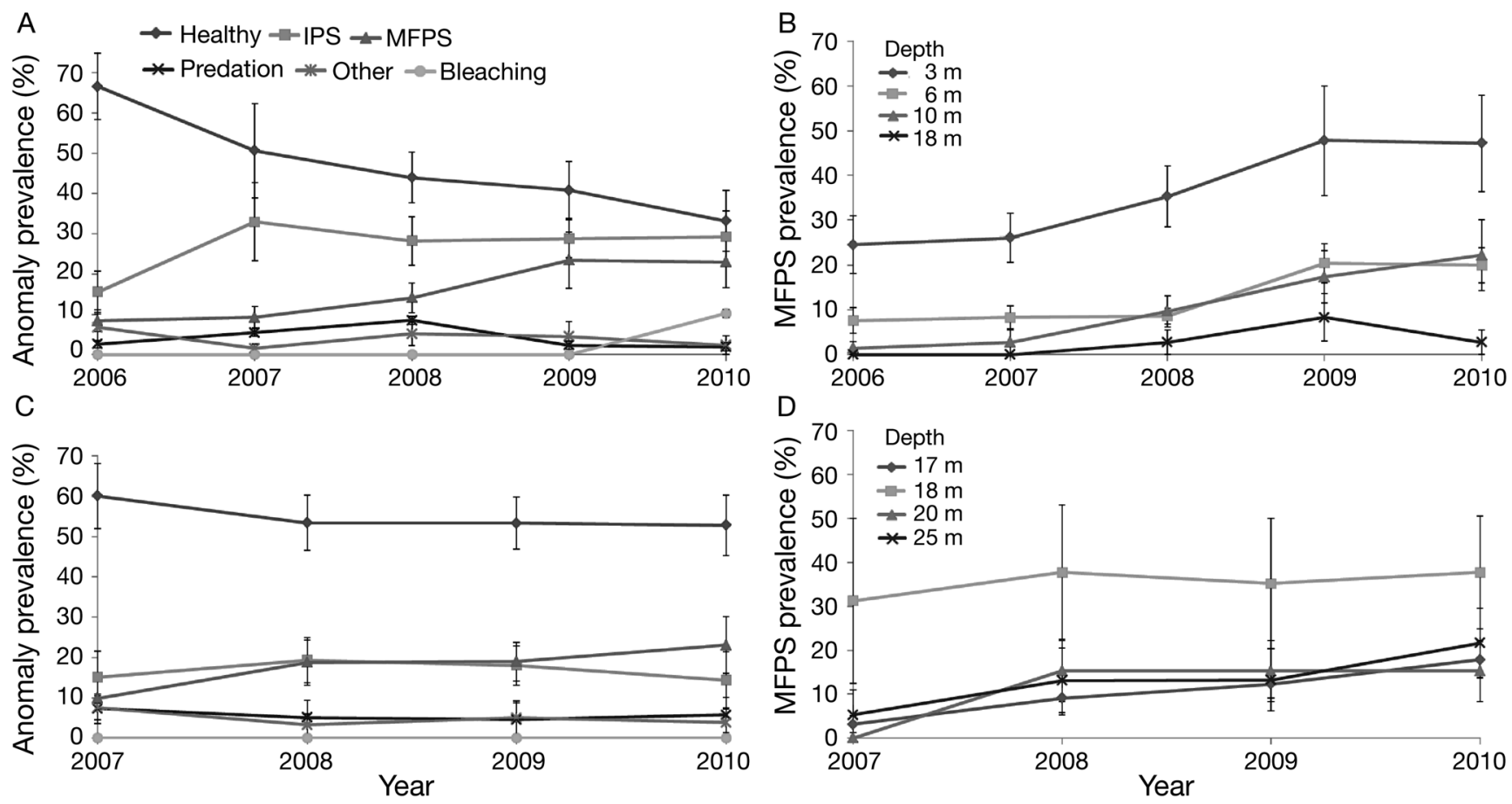

Fig. 3. Gorgonia ventalina. Prevalence of each anomaly $( \pm$ SE) in sea fans at $(A, B)$ Media Luna and $(C, D)$ Buoy reefs, La Parguera, Puerto Rico. Data are indicated as $(A, C)$ prevalence of abnormalities per site and (B,D) percent multifocal purple spots (MFPS) per depth. IPS: irregular purple spots 
on published descriptions of morphology of the trophic cells and sori of the Labyrinthulomycota (Porter 1990), the cultured Labyrinthulomycetes best matched the genus Aplanochytrium, a member of the Family Thraustochytridae. Similarly, Labyrinthulomycetes cultured on glass slides and stained with Giemsa included trophic cells (length $=10.22 \pm$ $0.15 \mu \mathrm{m}$, mean $\pm \mathrm{SE}$, range 4.41 to $16.12 \mu \mathrm{m}, \mathrm{n}=150)$, spores $(4.48 \pm 0.14 \mu \mathrm{m}, 2.36$ to $7.31, \mathrm{n}=57)$, and sori $(18.61 \pm 0.89 \mu \mathrm{m}, 12.77$ to $31.43, \mathrm{n}=225)$.

\section{Histological}

In both sea fans exhibiting MFPS ( $\mathrm{n}=8$; Table 1 ) and apparently healthy colonies $(n=7)$, tissue sections revealed ovoid to elongated trophic cells either solitary or undergoing binary fission and ectoplasmic networks (mucus) mainly within a spaceapparently where the proteinaceous gorgonin had split apart-usually just beneath the cortex of the axis or sometimes within the central chord or core of the axis (Fig. 4A). Labyrinthulomycetes cells averaged $9.51 \pm 0.47 \mu \mathrm{m}$ (range 5.61 to 16.3 ) in sea fans with MFPS ( $\mathrm{n}=100$ cells) and $8.49 \pm 0.38 \mu \mathrm{m}$ (range 4.9 to 13.4 ) in apparently healthy sea fans ( $\mathrm{n}=100$ cells) (Table 1). The presence of Labyrinthulomycetes cells was generally limited to relatively small areas of the sea fan colonies, and the majority of sea fans did not display any obvious tissue changes or damage other than the longitudinal splitting of the gorgonin axis described above. Occasionally, cells with a mucus trail (ectoplasmic net) were seen in the coenenchyme or sea fan
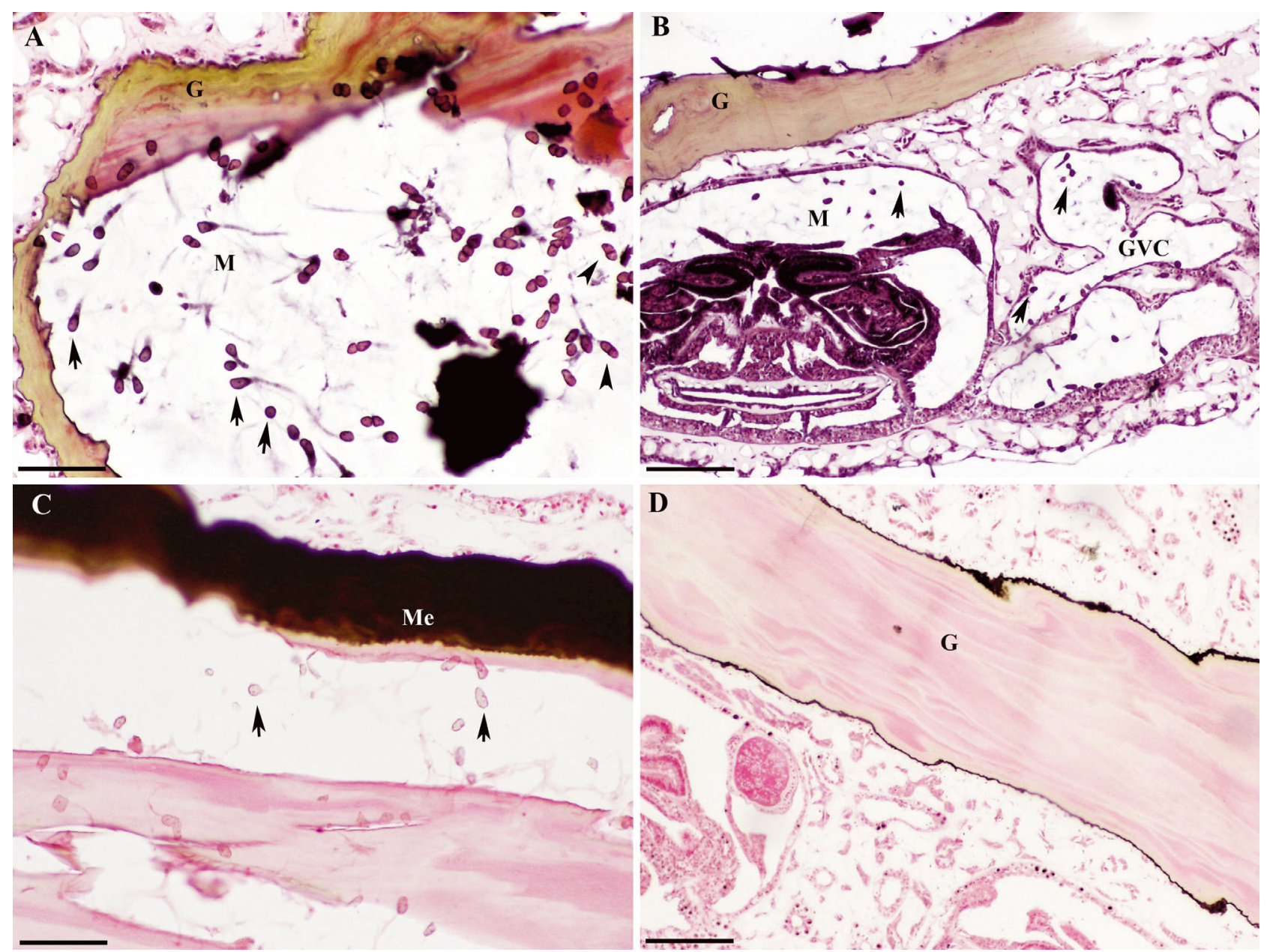

Fig. 4. Labyrinthulomycetes in Gorgonia ventalina showing trophic cells (arrows). (A) Labyrinthulomycetes within gorgonin (G) axis with mucus (M) and some trophic cells (arrows) undergoing binary fission. Hematoxylin and eosin (H\&E), scale bar = $50 \mu \mathrm{m}$. (B) Labyrinthulomycetes within a polyp and gastrovascular canals (GVC) and gorgonin. H\&E, scale bar = $100 \mu \mathrm{m}$. (C) Melanin deposition (Me) within gorgonin of $G$. ventalina infected with Labyrinthulomycetes. Fontana Mason (FM) stain, scale bar $=50 \mu \mathrm{m}$. (D) Gorgonin of uninfected G. ventalina lacking melanin. FM stain, scale bar $=100 \mu \mathrm{m}$ 
Table 1. Gorgonia ventalina. Presence of Labyrinthulomycetes in sea fans (SF) with multifocal purple spots (MFPS) and healthy sea fans collected at Media Luna Reef, La Parguera, Puerto Rico (July 2010) and summary data for sea fans collected at Big Pine Ledges, Florida (February 2010) based on histological and molecular evidence. Where positive PCR results were obtained using Labyrinthulomycetesspecific SSU rRNA primers (Stokes et al. 2002), sequence data indicate an Aplanochytrium sp. unless otherwise noted. nd: no data (Labyrinthulomycetes cells not measured); na: not applicable (no histological observations made)

\begin{tabular}{|c|c|c|c|}
\hline \multirow[t]{2}{*}{ Specimen } & \multirow{2}{*}{$\begin{array}{l}\text { PCR } \\
\text { result }\end{array}$} & \multicolumn{2}{|c|}{ Histology } \\
\hline & & Presence & $\begin{array}{c}\text { Mean } \pm \text { SE } \\
\text { length }(\mu \mathrm{m})(\mathrm{n})\end{array}$ \\
\hline \multicolumn{4}{|c|}{ MFPS sea fans (Puerto Rico) } \\
\hline MFPS SF 1 & + & + & nd \\
\hline MFPS SF 2 & + & - & \\
\hline MFPS SF 3 & + & + & $10.66 \pm 0.60(13)$ \\
\hline MFPS SF 4 & + & + & $8.38 \pm 0.35(16)$ \\
\hline MFPS SF 5 & + & + & $10.23 \pm 0.46(15)$ \\
\hline MFPS SF 6 & - & + & $8.75 \pm 0.53(11)$ \\
\hline MFPS SF 7 & - & - & \\
\hline MFPS SF 8 & - & - & \\
\hline MFPS SF 9 & - & - & \\
\hline MFPS SF 10 & - & + & nd \\
\hline MFPS SF 11 & - & - & \\
\hline MFPS SF 12 & - & - & \\
\hline MFPS SF 13 & - & + & $9.49 \pm 0.35(19)$ \\
\hline MFPS SF 14 & - & + & $9.56 \pm 0.55(28)$ \\
\hline MFPS SF 15 & - & - & \\
\hline \multicolumn{4}{|l|}{ Summary } \\
\hline Puerto Rico & $5 / 15$ & $8 / 15$ & $9.51 \pm 0.47$ \\
\hline Florida & $3 / 6$ & na & na \\
\hline \multicolumn{4}{|c|}{ Healthy sea fans (Puerto Rico) } \\
\hline Healthy SF 1 & - & - & \\
\hline Healthy SF 2 & $t^{\mathrm{a}}$ & + & $9.39 \pm 0.41(19)$ \\
\hline Healthy SF 3 & $t^{\mathrm{a}}$ & + & $7.62 \pm 0.62(9)$ \\
\hline Healthy SF 4 & - & - & \\
\hline Healthy SF 5 & - & + & $7.53 \pm 0.07(15)$ \\
\hline Healthy SF 6 & - & - & \\
\hline Healthy SF 7 & + & - & \\
\hline Healthy SF 8 & - & + & $8.73 \pm 0.61(10)$ \\
\hline Healthy SF 9 & - & - & \\
\hline Healthy SF 10 & - & - & $7.54 \pm 0.07$ \\
\hline Healthy SF 11 & + & - & \\
\hline Healthy SF 12 & $+{ }^{\mathrm{b}}$ & + & $9.77 \pm 0.67(7)$ \\
\hline Healthy SF 13 & $t^{\mathrm{b}}$ & + & $9.86 \pm 0.51(16)$ \\
\hline Healthy SF 14 & - & - & \\
\hline Healthy SF 15 & $++^{\mathrm{b}}$ & + & $7.54 \pm 0.65(8)$ \\
\hline \multicolumn{4}{|l|}{ Summary } \\
\hline Puerto Rico & $7 / 15$ & $7 / 15$ & $8.49 \pm 0.38$ \\
\hline Florida & $3 / 5$ & na & na \\
\hline
\end{tabular}

polyps (Fig. 4B). In 2 of the sea fan colonies analyzed, infections were more systemic where large numbers of Labyrinthulomycetes cells were visualized and colonies were devoid of polyps. No apparent entry point or mode of entry was observed.
Invertebrates, including copepods and worms, were also observed in the coenenchyme within grossly purple MFPS tissue of some $(6.7 \%$ of apparently healthy and 33\% of MFPS, $20 \%$ of which were accompanied by Labyrinthulomycetes infections) of the sea fans. Fungal hyphae were also noted in the axis of 1 MFPS sea fan and 2 apparently healthy sea fans ( $\mathrm{n}=15$ respectively), alongside infection with the Labyrinthulomycetes.

FM staining indicated a host melanization response only in areas where Labyrinthulomycetes or fungi were present (Fig. 4C), and in most fans examined (7 out of 8 ), melanization occurred with Labyrinthulomycetes infection. In the one fan where melanization was not detected, only 2 Labyrinthulomycetes cells were noted. Nonmelanized gorgonin ranged in color from pink in the axis center (or clear) to light brown or tan (Fig. 4D).

\section{Molecular}

Detectable PCR products were amplified with primers targeting the phylum Labyrinthulomycota (Stokes et al. 2002) from the cultured cells and many of the field-collected samples as follows: 4 out of 5 healthy colonies from Florida, 3 out of 6 MFPS samples from Florida, 7 out of 15 healthy samples from Puerto Rico, and 5 out of 15 MFPS samples from Puerto Rico (Table 1).

Alignment of all of the Labyrinthulomycota SSU rRNA sequences derived from the cultured cells, healthy and MFPS sea fan tissue from Florida strongly suggests that the 3 sources contain the same microorganism. All of the sea fan derived sequences are identical to one another within this amplified SSU rRNA region. This sequence is also identical (100\% similarity) to multiple SSU rRNA sequences in the NCBI database from the genus Aplanochytrium/ Labyrinthuloides (synonymized by Leander \& Porter 2000 as Aplanochytrium), suggesting that the sea fan isolate is very likely a member of this genus in the family Thraustochytridae.

Of the Puerto Rico samples that amplified with the Labyrinthulomycota SSU rRNA primers, 5 healthy and 4 MFPS were sequenced. Of these, 2 of the Labyrinthulomycetes sequences isolated from the apparently healthy sea fans matched the genus Thraustochytrium in the NCBI database based on identical sequences $(100 \%)$ to multiple SSU rRNA sequences of the genus Thraustochytrium. The remaining healthy and MFPS-fan derived sequences appear to belong to the same Aplanochytrium genus as the Florida isolates (Table 1). 
Temperature and growth optima

Labyrinthulomycetes growth was quantified using cell counts in 2 trials. Total cell counts reported for Trial 1 indicated that growth was directly related to culture temperature (ANOVA, $\mathrm{p}<0.0001$ ), with the following statistical trend: $15^{\circ} \mathrm{C}<20^{\circ} \mathrm{C}<25^{\circ} \mathrm{C}<$ $32^{\circ} \mathrm{C}=30^{\circ} \mathrm{C}$ (Tukey test, $\mathrm{p}<0.05$, Fig. $5 \mathrm{~A}$ ). A similar trend was observed in total cells for the second trial: $20^{\circ} \mathrm{C}<25^{\circ} \mathrm{C}<30^{\circ} \mathrm{C}$ (Tukey test, $\mathrm{p}<0.05$ ), although cell counts were different between trials $(p=0.037)$. In the second trial, where cell types were differentiated, counts differed significantly in total sori $(\mathrm{p}<$ 0.003 ) and total trophic cells between temperatures (ANOVA, $\mathrm{p}<0.001$ ): sori $20^{\circ} \mathrm{C}=25^{\circ} \mathrm{C}<30^{\circ} \mathrm{C}$ (Tukey test, $\mathrm{p}<0.05$ ), and trophic cells $20^{\circ} \mathrm{C}<25^{\circ} \mathrm{C}<30^{\circ} \mathrm{C}$ (Tukey test, $\mathrm{p}<0.05$; Fig. 5B). Total protein content in Trial 2 (Fig. 5C) was similar for cell cultures grown at $20^{\circ} \mathrm{C}\left(8.55 \pm 0.89 \mathrm{mg}\right.$ protein culture $\left.{ }^{-1}\right)$ and $25^{\circ} \mathrm{C}$ $\left(8.96 \pm 0.51 \mathrm{mg}\right.$ protein culture $\left.{ }^{-1}\right)$, which were significantly lower than those held at $30^{\circ} \mathrm{C}(11.09 \pm 0.84$ mg protein culture $\left.{ }^{-1}\right)\left(20^{\circ} \mathrm{C}=25^{\circ} \mathrm{C}<30^{\circ} \mathrm{C}\right.$; ANOVA: $\mathrm{p}<0.0001$, Tukey test: $\mathrm{p}<0.05$ ).

\section{Inoculation experiments}

The inoculation experiments did not provide evidence of new Labyrinthulomycetes infections, as Labyrinthulomycetes cells were detected by histology in both control and inoculation treatments. In the first trial, Labyrinthulomycetes cells were visualized in 5 of the control replicates and 4 of the inoculated treatments $(n=12$ colonies each; 2 colonies contained Labyrinthulomycetes cells in both control and treatment replicates). In the second trial, 1 lesion developed in each of 2 sea fans held in bath treatment with Labyrinthulomycetes cells: 1 sea fan contained Labyrinthulomycetes cells in association with the developed lesion. However, Labyrinthulomycetes cells were also detected in all of the control and bath treatment samples from these colonies.

\section{DISCUSSION}

The first step to validate disease etiology is pathogen isolation and characterization, and for the first time, Labyrinthulomycetes cells were isolated, cultured, and characterized from sea fans with MFPS. Identical sequence data were obtained from sea fans with MFPS from Florida and Puerto Rico, as well as most apparently healthy sea fans from both localities:
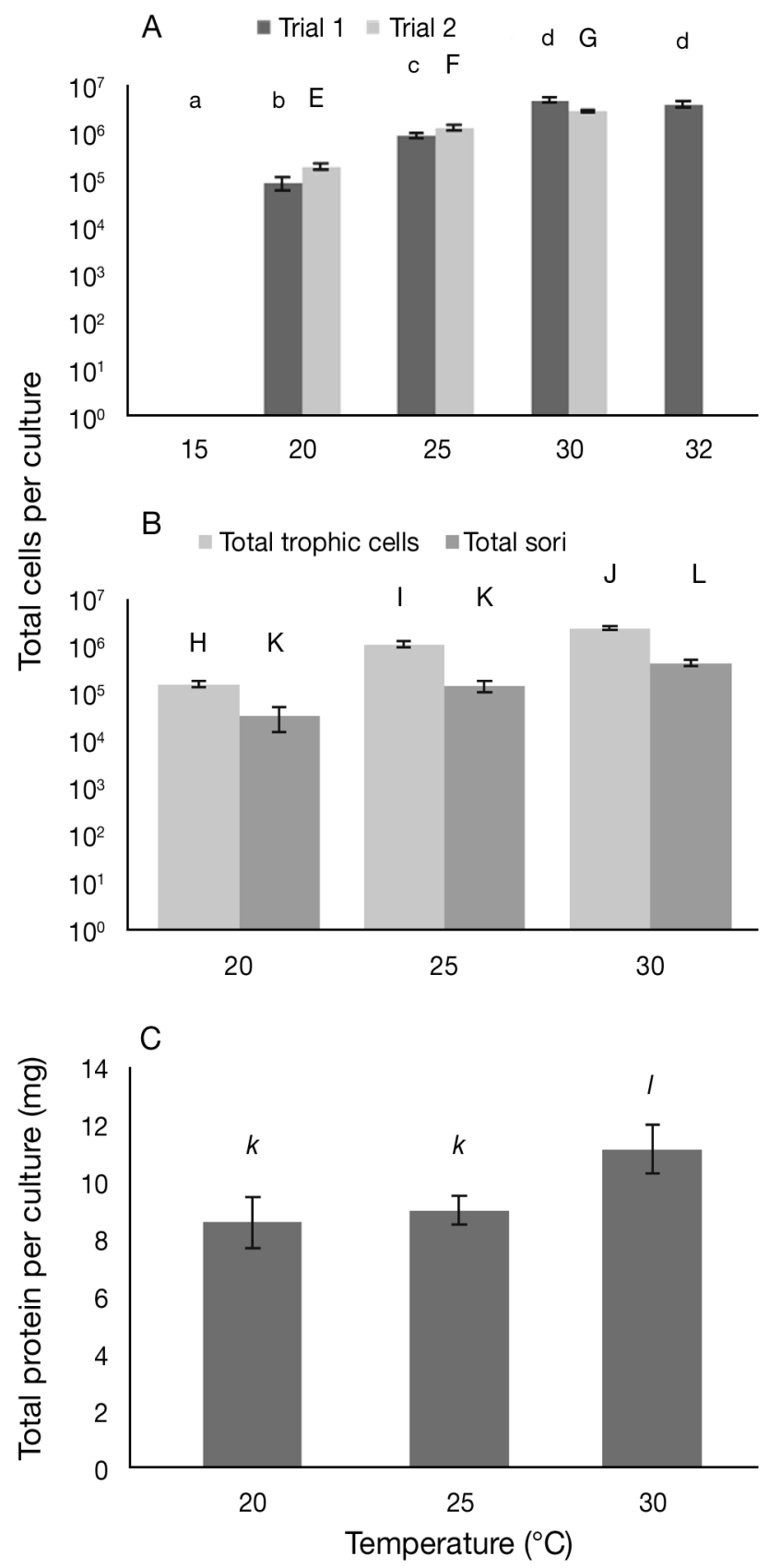

Fig. 5. Temperature and growth optima of Aplanochytrium spp. cells measured using $(A, B)$ cell counts and $(C)$ total protein concentrations in two trials. Statistical significance $(p<$ 0.05 ) is indicated with lower-case letters for cell counts in Trial 1, upper-case letters for cell counts in Trial 2, and italics for protein concentration in Trial 2. (A) Mean $( \pm$ SE) of total Aplanochytrium spp. cells per culture at different temperatures in 2 trials. Significant differences among total cell counts were found among treatments $(p<0.0001)$ and between trials $(p=0.037)$. (B) Mean $( \pm \mathrm{SE})$ number of Aplanochytrium spp. cell types (sori or trophic cells) per culture at different temperatures in Trial 2 where significant differences were found in total trophic cells $(p<0.001)$, and total sori $(p<0.003)$. (C) Mean $( \pm S E)$ of total protein concentration for cultures at different temperatures in Trial 2 
Labyrinthulomycetes from the genus Aplanochytrium. However, a second Labyrinthulomycetes sequence was detected in 2 healthy individuals collected in PR, a Labyrinthulomycetes of the genus Thraustochytrium. Observations including general pathology and morphology of cells (size) in sea fans from PR indicate that infections by Labyrinthulomycetes are localized within colonies (Table 1) and that Aplanochytrium and Thraustochytrium may be indistinguishable. The observation of Labyrinthulomycetes in both apparently healthy and MFPS sea fans implies an opportunist, like many marine pathogens: often present in the marine environment but only pathogenic under some conditions. Therefore, additional work is needed to understand the pathogenesis of Labyrinthulomycetes in sea fans including whether MFPS are formed in response to Labyrinthulomycetes infections. Based on $5 \mathrm{yr}$ of survey data collected off La Parguera, PR, incidence of MFPS is increasing in sea fan colonies, particularly MFPS at shallow depths. This indication of an emerging disease compels further characterization of the relationship between MFPS and biotic invaders.

Labyrinthulomycetes have been previously associated with apparently healthy cnidarian hosts (based on either light or electron microscopy or both) including hydroids (Raghukumar 1988) and scleractinian corals (Kramarsky-Winter et al. 2006, Siboni et al. 2010). Based on 18S rRNA sequences, Labyrinthulomycetes from the family Thraustochytriidae were associated with scleractinian corals: Fungia granulosa in the Gulf of Eliat (/Aqaba) (genera unknown, Harel et al. 2008) and with Favia spp. from both the Gulf of Eliat (/Aqaba) and the Great Barrier Reef (Aplanochytrium sp, Thraustochytrium sp, and Labyrinthuloides sp., Siboni et al. 2010). These results are similar to the molecular analyses of Labyrinthulomycetes present in sea fan colonies described in the present study. In scleractinian corals, Labyrinthulomycetes can form white patches on the host surface (Kramarsky-Winter et al. 2006) and have been described in the mucus, coral surface, and coral tissues (Raghukumar \& Balasubramanian 1991, Kramarsky-Winter et al. 2006, Siboni et al. 2010). The Labyrinthulomycetes-scleractinian relationship may be mutualistic or commensal, with the thraustochytrids providing the host with nutrition and nutrient cycling in exchange for coral mucus as a carbon source (Siboni et al. 2010).

Unlike the mutualistic Labyrinthulomycetes relationships described in other cnidarians, our histological evidence suggests a parasitic relationship. In many infected sea fans, evidence of poor health included longitudinal splitting of the gorgonin axis, patches of Labyrinthulomycetes aggregations surrounded by melanized gorgonin and lack of polyps in colonies with the highest intensity infections. However, whether poor health is caused by Labyrinthulomycetes infection or compromised individuals allow the opportunistic Labyrinthulomycetes to invade is unknown. Melanin staining suggests a host response to the Labyrinthulomycetes, and similar melanin staining has been previously observed in purple tissue and axis of sea fans infected with fungus (Mydlarz et al. 2008) and/or Labyrinthulomycetes (Petes et al. 2003) as well as in pigmented Porites spp. (Palmer et al. 2008). Melanin encapsulation is a key component of the invertebrate immune response and is well characterized in insects and crustaceans (reviewed by Rowley 1996, Cerenius et al. 2010). Similarly, the melanization response plays a role in scleractinian wound healing (Palmer et al. 2011). Labyrinthulomycetes infections, similar to fungal infections of sea fans, appear to be opportunistic; both parasite types appear most frequently within the sea fan axis. It has been hypothesized that the skeleton may have lower levels of anti-bacterial (Kim et al. 2000) and anti-fungal compounds (Kim et al. 2000, Dube et al. 2002, Ward 2007, Ward et al. 2007) than are found in the coenenchyme (Ward et al. 2007), perhaps allowing initial infection. The melanization response by amoebocytes (Mydlarz et al. 2008) builds a thick wall over the fungus or Labyrinthulomycetes, in an effort to encapsulate or kill the parasites or perhaps to strengthen the axis. It appears that both parasites weaken the gorgonin by lateral spread of the hyphae or mucus net through the gorgonin or splitting it apart as the number of parasite cells and mucus increase, which weakens the gorgonin so the sea fan blade may be more susceptible to breakage from storm-driven wave and current damage.

Despite 2 inoculation trials, there was no evidence of cultured Labyrinthulomycetes infecting sea fans. In fact, histological evidence from these trials further corroborates that Labyrinthulomycetes are found in otherwise healthy sea fans. One possible explanation for this observation is that the sea fan colonies used in these experiments had been previously exposed and infected and may not be susceptible to re-infection, or that susceptible individuals were already infected, thus masking any Aplanochytrium cells acquired by exposure. Another explanation is that although both injection and bath challenges were attempted, possibly they did not replicate the Labyrinthulomycetes mode of entry into the sea fan 
tissues and axial skeleton or that the cultured cells were no longer infectious. Experimental inoculation trials were run within a temperature range that should be favorable for Aplanochytrium growth $\left(28\right.$ to $\left.32^{\circ} \mathrm{C}\right)$. The optimal growth-temperature was $30^{\circ} \mathrm{C}$, similar to that of Aspergillus sydowii (Alker et al. 2004, Ward et al. 2007). In fact, fungal growth decreased at $31^{\circ} \mathrm{C}$ coincident with maximum sea fan host anti-fungal activity (Ward et al. 2007).

Pathogen-growth optima in culture may not translate directly to the dynamic seen in a host-pathogen relationship where host immune response and the pathogen growth have a complex interplay (Dahl et al. 2011, Perrigault et al. 2011). For example, although in vitro growth of the QPX, a thrautochytrid parasite of quahog clams, Mercenaria mercenaria, is greatest between $20^{\circ} \mathrm{C}$ and $23^{\circ} \mathrm{C}$ (Perrigault et al. 2010), both natural and experimentally produced infections in quahogs were more severe (based on prevalence and mortality) at $13^{\circ} \mathrm{C}$ (compared to $21^{\circ} \mathrm{C}$ and $27^{\circ} \mathrm{C}$ ), where host immune responses were compromised (Perrigault et al. 2011). QPX infections are chronic, and QPX is regularly detected in healthy individuals, indicating an opportunistic parasite. In fact, both QPX strains and host genetics are important in the virulence of QPX disease (Dahl et al. 2008). This complex interplay of QPX disease in hard clams may provide clues to better understanding the sea fan-Labyrinthulomycetes relationship, as the same factors may be important for disease transmission and host immunity.

In conclusion, Labyrinthulomycetes of the family Thraustochytridae appear to be opportunistic parasites of sea fan corals. Although Labyrinthulomycetes were detected in association with MFPS, MFPS do not always indicate Labyrinthulomycetes infections and are likely a host response to biotic stressors. Additional time course sampling and surveys of natural populations may clarify the relationship between MFPS and Labyrinthulomycetes infection. The increase in purple spots may indicate compromised health in sea fans around La Parguera, PR. This hypothesis is supported by increases in disease in other corals species in this area (E. Weil pers. obs.) and in coral disease in the Caribbean and globally over the past 2 decades (Harvell et al. 2004, 2007).

Acknowledgements. This work was conducted under National Science Foundation grant number OCE0849776. Initial parasite isolation was supported, in part, by the School of Aquatic and Fishery Sciences at the University of Washington. Florida sea fan corals were collected by E. Bartels of the Mote Tropical Research Laboratory on Summer- land Key under Florida Keys National Marine Sanctuary permit number FKNMS-2008-001. The authors thank C. S. Couch and E. Peters for editorial comments. The Department of Marine Sciences University of Puerto Rico provided logistical support for field work and lab experiments.

\section{LITERATURE CITED}

Alker AP, Kiho K, Dube DH, Harvell CD (2004) Localized induction of a generalized response against multiple biotic agents in Caribbean sea fans. Coral Reefs 23: 397-405

Altschul SF, Gish W, Miller W, Myers EW, Lipman DJ (1990) Basic local alignment search tool. J Mol Biol 215:403-410

Bourne DG, Garren M, Work TM, Rosenberg E, Smith GW, Harvell CD (2009) Microbial disease and the coral holobiont. Trends Microbiol 17:554-562

Bower SM (1987) Labyrinthuloides haliotidis n. sp. (Protozoa: Labyrinthomorpha), a pathogenic parasite of small juvenile abalone in a British Columbia mariculture facility. Can J Zool 65:1996-2007

Cerenius L, Kawabata SI, Lee BL, Nonaka M, Söderdäll K (2010) Proteolytic cascades and their involvement in invertebrate immunity. Trends Biochem Sci 35:575-583

Dahl SF, Perrigault M, Allam B (2008) Laboratory transmission studies of QPX disease in the hard clam: interactions between different host strains and pathogen isolates. Aquaculture 280:64-70

Dahl SF, Perrigault M, Liu Q, Collier JL, Barnes DA, Allam B (2011) Effects of temperature on hard clam (Mercenaria mercenaria) immunity and QPX (Quahog Parasite Unknown) disease development: I. Dynamics of QPX disease. J Invertebr Pathol 106:314-321

> Dube D, Kim K, Alker AP, Harvell CD (2002) Size structure and geographic variation in chemical resistance of sea fan corals Gorgonia ventalina to a fungal pathogen. Mar Ecol Prog Ser 231:139-150

Durako MJ, Kuss KM (1994) Effects of Labyrinthula infection on the photosynthetic capacity of Thalassia testudinum. Bull Mar Sci 54:727-732

- Geiser DM, Taylor JW, Ritchie KB, Smith GW (1998) Cause of sea fan death in the West Indies. Nature 394: $137-138$

> Goujon M, McWilliam H, Li W, Valentin F, Squizzato S, Paern J, Lopez R (2010) A new bioinformatics analysis tools framework at EMBL-EBI. Nucleic Acids Res 38(Suppl):W695-W699

Harel M, Ben-Dov E, Rasoulouniriana D, Siboni N and others (2008) A new Thraustochytrid, strain Fng1, isolated from the surface mucus of the hermatypic coral Fungia granulosa. FEMS Microbiol Ecol 64:378-387

> Harvell CD, Aronson R, Baron N, Connell J and others (2004) The rising tide of ocean diseases: unsolved problems and research priorities. Front Ecol Environ 2: 375-382

Harvell CD, Jordan-Dahlgren E, Merkel S, Rosenberg E and others (2007) Coral disease, environmental drivers and the balance between coral and microbial associates. Oceanography 20:58-81

Kim K, Harvell CD (2001) Aspergillosis of sea fan corals: disease dynamics in the Florida Keys. In: Porter JW, Porter KG (eds) The Everglades, Florida Bay, and coral reefs of the Florida Keys: an ecosystem sourcebook. CRC Press, New York, NY, p 813-824 
Kim K, Kim PD, Alker AP, Harvell CD (2000) Chemical resistance of gorgonian corals against fungal infections. Mar Biol 137:393-401

Kleinschuster SJ, Smolowitz R, Parent J (1998) In vitro life cycle and propagation of quahog parasite unknown. J Shellfish Res 17:75-78

Kramarsky-Winter E, Harel M, Siboni N, Ben Dov E, Brickner I, Loya Y, Kushmaro A (2006) Identification of a protist-coral association and its possible ecological role. Mar Ecol Prog Ser 317:67-73

Larkin MA, Blackshields G, Brown NP, Chenna R and others (2007) ClustalW and ClustalX version 2. Bioinformatics 23:2947-2948

Leander CA, Porter D (2000) Redefining the genus Aplanochytrium (phylum Labyrinthulomycota). Mycotaxon 76: 439-444

Luna LG (ed) (1968) Manual of histologic staining methods of the Armed Forces Institute of Pathology, 3rd edn. McGraw-Hill, New York, NY

> Lyons MM, Smolowitz R, Gomez-Chiarri M, Ward JE (2007) Epizootiology of quahog parasite unknown (QPX) disease in northern quahogs (=hard clams) Mercenaria mercenaria. J Shellfish Res 26:371-381

McLean N, Porter D (1982) The yellow-spot disease of Tritonia diomedea Bergh, 1894 (Mollusca: Gastropoda: Nudibranchia): encapsulation of the Thraustochytreaceous parasite by host amoebocytes. J Parasitol 68:243-252

> Muehlstein LK, Porter D, Short FT (1991) Labyrinthula zosterae sp. nov., the causative agent of wasting disease of eelgrass, Zostera marina. Mycologia 83:180-191

Mydlarz LD, Holthouse SF, Peters EC, Harvell CD (2008) Cellular responses in sea fan corals: granular amoebocytes react to pathogen and climate stressors. PLoS ONE 3:e1811

Nagelkerken I, Buchan K, Smith GW, Bonair K and others (1997) Widespread disease in Caribbean sea fans: I. Spreading and general characteristics. Proc 8th Coral Reef Symp, Panama City 1:679-682

Palmer CV, Mydlarz LD, Willis BL (2008) Evidence of an inflammatory-like response in non-normally pigmented tissues of two scleractinian corals. Proc R Soc Lond B Biol Sci 275:2687-2693

Palmer CV, Traylor-Knowles NG, Willis BL, Bythell JC (2011) Corals use similar immune cells and wound-healing processes as those of higher organisms. PLoS ONE 6: e23992

Perrigault M, Buggé DM, Allam B (2010) Effect of environmental factors on survival and growth of quahog parasite unknown (QPX) in vitro. J Invertebr Pathol 104:83-89

Perrigault M, Dahl SF, Pales Espinosa E, Gambino L, Allam B (2011) Effects of temperature on hard clam (Mercenaria mercenaria) immunity and QPX (quahog parasite unknown) disease development: II. Defense parameters. J Invertebr Pathol 106:322-332

Petes LE, Harvell CD, Peters EC, Webb MAH, Mullen KM (2003) Pathogens compromise reproduction and induce melanization in Caribbean sea fans. Mar Ecol Prog Ser 264:167-171

Polglase JL (1980) A preliminary report on the Thraustochytrid(s) and Labyrinthulid(s) associated with a pathological condition in the lesser octopus Eledone cirrhosa. Bot Mar 23:699-706

Porter D (1990) Phylum Labyrinthulomycota. In: Margulis L, Corliss JO, Melkonian M, Chapman DJ (eds) The hand- book of Protoctista. Jones and Bartlett, Boston, MA, p 388-398

- Ragan MA, MacCallum GS, Murphy CA, Cannone JJ, Gutell RR, McGladdery SE (2000) Protistan parasite QPX of hard-shell clam Mercenaria mercenaria is a member of Labyrinthulamycota. Dis Aquat Org 42:185-190

Raghukumar S (1988) Detection of the thraustochytrid protist Ulkenia visurgensis in a hydroid, using immunofluorescence. Mar Biol 97:253-258

Raghukumar S, Balasubramanian R (1991) Occurrence of thraustochytrid fungi in corals and coral mucus. Indian $\mathrm{J}$ Mar Sci 20:176-181

- Ragone Calvo LM, Walker JG, Burreson EM (1998) Prevalence and distribution of QPX, Quahog Parasite Unknown, in hard clams Mercenaria mercenaria in Virginia, USA. Dis Aquat Org 33:209-219

Ralph PJ, Short FT (2002) Impact of the wasting disease pathogen, Labyrinthula zosterae, on the photobiology of eelgrass Zostera marina. Mar Ecol Prog Ser 226: 265-271

Rowley AF (1996) The evolution of inflammatory mediators. Mediators Inflamm 5:3-13

> Siboni N, Rasoulouniriana D, Ben-Dov E, Kramarsky-Winter E and others (2010) Stramenopile microorganisms associated with the massive coral Favia sp. J Eukaryot Microbiol 57:236-244

Smith GW, Weil E (2004) Aspergillosis in gorgonians. In: Rosemberg E, Loya Y (eds) Coral reef health and disease. Springer-Verlag, Berlin, p 279-286

Smith GW, Ives LD, Nagelkerken IA, Ritchie KB (1996) Caribbean sea-fan mortalities. Nature 383:487

Stokes NA, Ragone Calvo LM, Reece KS, Burreson EM (2002) Molecular diagnostics, field validation, and phylogenetic analysis of Quahog Parasite Unknown (OPX), a pathogen of the hard clam Mercenaria mercenaria. Dis Aquat Org 52:233-247

Sutherland KP, Porter JW, Torres C (2004) Disease and immunity in Caribbean and Indo-Pacific zooxanthellate corals. Mar Ecol Prog Ser 266:273-302

Toledo-Hernández C, Zulaga-Montero A, Bones-González A, Rodríguez JA, Sabat AM, Bayman P (2008) Fungi in healthy and diseased sea fans (Gorgonia ventalina): Is Aspergillus sydowii always the pathogen? Coral Reefs 27:707-714

> Ward JR (2007) Within-colony variation in inducibility of coral disease resistance. J Exp Mar Biol Ecol 352: 371-377

> Ward JR, Kim K, Harvell CD (2007) Temperature affects coral disease resistance and pathogen growth. Mar Ecol Prog Ser 329:115-121

Weil E, Hooten AJ (2008) Underwater cards for assessing coral health on Caribbean coral reefs. Coral Reef Targeted Research Program, St Lucia

Weil E, Rogers CS (2011) Coral reef diseases in the AtlanticCaribbean. In: Dubinsky Z, Stambler N (eds) Coral reefs: an ecosystem in transition, 1st edn. Springer-Verlag, Berlin, p 465-492

> Weil E, Smith GW, Gil-Agudelo DL (2006) Status and progress in coral reef disease research. Dis Aquat Org 69:1-7

> Work TM, Aeby GS (2006) Systematically describing gross lesions in corals. Dis Aquat Org 70:155-160

Zar JH (1999) Biostatistical analysis, 4th edn. Prentice Hall, Upper Saddle River, NJ 